Each of these agents is of benefit in the management of advanced Hodgkin's disease, though the order in which they should be used has not yet been established, nor have the results of treatment with combinations of these agents been adequately explored.

We wish to thank Dr. John Marks, of Roche Products Ltd., for generous supplies of procarbazine (Natulan).

\section{REFERENCES}

Armstrong, J. G., Dyke, R. W., Fouts, P. J., and Gahimer, J. E. (1962). Cancer Chemother. Rep., 18, 49.

Bethell, F. H., Louis, J., Robbins, A., Donnelly, W. J., Dessel, B. H., Battle, J. D., Pisciotta, A. V., Will, J., and Clifford, G. O. (1960). Ibid., 8, 112 .

Bleehen, N. M., and Jelliffe, A. M. (1965). Brit. F. Cancer, 19, 268.

Cohen, B. M., Smetana, H. F., and Miller, R. W. (1964). Cancer (Philad.), 17, 856

Dawson $W$. B. (1965). Natulan (Ibenzmethyzin), edited by A. A. Jelliffe and J. Marks, p. 31. Wright, Bristol. Easson, E. C., and Russell, M. H. (1963). Brit. med. F., 1, 1704. phamide. Wright, Bristol.

Fayos, J., Hendrix, R., Macdonald, V., and Lampe, I. (1965). Amor. F. Roentgenol., 93, 557.
Frost, J. W., Goldwein, M. I., and Bryan, J. A. (1962). Ann. intern. Med., 56, 854 .

Hill, J. M., and Loeb, E. (1961). Cancer Chemother. Rep., 15, 41.

Hodes, M. E., Rohn, R. J., and Bond, W. H. (1960). Cancer Res., 20, 1041.

Hope-Stone, H. F. (1965). Natulan (Ibenzmethyzin) edited by A. M. Jelliffe and J. Marks, p. 15. Wright, Bristol.

Jelliffe, A. M., Bleehen, N. M., and Fenner, M. L. (1965). Ibid., p. 35. Kaplan, H. S. (1962). Radiology, 78, 553.

Lacher, M. J., and Durant, J. R. (1965). Ann. intern. Med., 62, 468.

Marsden, J. A. (1963). Med. F. Aust., 2, 100.

Mathé, G., Berumen, L., Schweisguth, O., Brule, G., Schneider, M. Cattan, A., Amiel, J. L., and Schwarzenberg, L. (1963). Lancet, 2, 1077 .

- Schweisguth, O., Brule, G., Amiel, J. L., Cattan, A., Thomas, M., and Zamet, P. (1962). Presse méd., 70, 1349.

Matthias, J. Q., Misiewicz, J. J., and Scott, R. B. (1960). Brit. med. F., 2, 1837.

Newall, J., and Pringle, J. F. (1965). Scot. med. F., 10, 288.

Newton, K. A. (1965). Natulan (Ibenzmethyzin), edited by A. M. Jelliffe and J. Marks, p. 26. Wright, Bristol.

Peters, M. V., and Middlemiss, K. C. H. (1958). Amer. 7. Roentgenol., 79, 114 .

Rundles, R. W., Laszlo, J., Garrison, F. E., jun., and Hobson, J. B. (1962). Cancer Chemother. Rep., 16, 407.

Todd, I. D. H. (1965a). Brit. med. F., 1, 628.

- (1965b). Natulan (Ibenzmethyzin), edited by A. M. Jelliffe and J. Marks, p. 20. Wright, Bristol.

Wright, T. L., Hurley, J., Korst, D. R., Monto, R. W., Rehn, R. J., Will, J. J., and Louis, J. (1963). Cancer Res., 23, i69.

\title{
Iron Absorption in Idiopathic Haemochromatosis before, during, and after Venesection Therapy
}

\author{
ROGER WILLIAMS, ${ }^{*}$ M.D., M.R.C.P. ; F. MANENTI, † M.D. ; H. S. WILLIAMS, $\ddagger$ M.SC., F.INST.P. \\ C. S. PITCHER, $\S$ D.M., M.C.PATH.
}

Brit. med. F., 1966, 2, 78-81

The aetiology of idiopathic haemochromatosis is disputed. Sheldon's (1935) postulate that the basic defect is an inborn error of metabolism causing increased iron absorption was largely based on the description of familial cases. Subsequent experience has shown that these are rare, though recent surveys by Williams et al. $(1962,1965)$ have revealed a high incidence of minor clinical signs, hepatic siderosis, and increased iron absorption in the immediate relatives. MacDonald (1964), however, impressed by the frequent clinical association of haemochromatosis with alcoholism, postulates that the disorder is acquired. In his view iron absorption is normal and the excess body iron results from the high iron content of certain alcoholic drinks. The cirrhosis is unrelated to the iron deposition and results from the coincidence of further environmental factors such as malnutrition, alcoholism, or previous viral hepatitis.

To date there have been relatively few measurements of iron absorption in haemochromatosis. The results are conflicting, and it has been suggested that absorption may be depressed by the time of presentation as a result of saturation of the iron stores. A few studies have shown increased absorption after venesection therapy (Peterson and Ettinger, 1953 ; Chodos et al., 1957 ; Pirzio-Biroli et al., 1958). This question is also important therapeutically in relation to the use and value of venesection therapy in the removal of the excess tissue-iron

\footnotetext{
* Consultant Physician, Department of Gastroenterology, Southampton General Hospital, Southampton. Formerly Lecturer in Medicine, College Hospital, London.

+ British Council Scholar.

† Brinish Council Scholar.

† Principal Hospital Physicist, Royal Free Hospital, London. Hospital, London.
}

and its subsequent maintenance at a normal level. For these reasons we have measured iron absorption serially at various intervals before, during, and after treatment, and in this paper report the results of 37 measurements in 19 male patients with idiopathic haemochromatosis. In a number of patients examined after completion of venesection therapy the plasma iron turnover was also measured.

\section{Material and Methods}

At the time of presentation all the patients had shown abnormal skin pigmentation and hepatomegaly. Diabetes or impaired carbohydrate tolerance was present in 12 and hypogonadism in 10. With one exception (Case 12) the diagnosis had been confirmed by liver biopsy, this showing both cirrhosis and marked iron deposition (grade 4 of Scheuer et al., 1962). The serum iron level varied, but all had a percentage saturation of the total iron-binding capacity of greater than $60 \%$. Cases $2,3,12,17$, and 19 gave a history of excessive alcohol consumption over a number of years before presentation. Beer and spirits were the main drinks consumed, with the exception of the one (Case 2) who had drunk mainly wine. Cases 2, 4, 8, 9, $10,13,15,17$, and 19 correspond to propositi in families $\mathrm{N}, \mathrm{U}$, $\mathrm{R}, \mathrm{S}, \mathrm{L}, \mathrm{P}, \mathrm{E}, \mathrm{F}$, and $\mathrm{O}$ in the previous reports of Williams et al. $(1962,1965)$.

The serum iron and total iron-binding capacity were estimated by Ramsay's (1957) method, 2, 2' 2" tripyridyl being used as the colour reagent. The blood was taken in the morning after an overnight fast. Plasma iron turnover was determined according to standard techniques (Dacie and Lewis, 1963). 


\section{Iron Absorption}

This was measured in most cases by a modification of the double isotope technique of Saylor and Finch (1953). ${ }^{55} \mathrm{Fe}$ was given orally as a solution of ferric chloride during a standard lunch consisting of corned beef and potato salad followed by mixed fruit salad (total iron content $9.5-10.5 \mathrm{mg}$.). ${ }^{59} \mathrm{Fe}$-labelled plasma was injected intravenously at the same time. At 14 days a blood sample was taken and the activities of the two isotopes in the red cells were determined by differential counting after digestion of the blood and electroplating of the iron. The ${ }^{59} \mathrm{Fe}$ counts indicated the percentage of plasma iron used for haemoglobin synthesis, and the percentage utilization of the absorbed ${ }^{55} \mathrm{Fe}$ was assumed to be the same. Thus if $50 \%$ of the ${ }^{59} \mathrm{Fe}$ administered appeared in the red cells, then the amount of ${ }^{55} \mathrm{Fe}$ detected there was taken to represent $50 \%$ of that absorbed. When tests were repeated a blood sample was taken before the meal and allowance made in the calculation for persisting radioactivity. Full details are given elsewhere (Pitcher et al., 1965).

In some recent tests the absorption was measured by means of a whole-body counter. This consisted of a heavily shielded 5 by $3 \frac{1}{2}$-in. ( 12.5 by $9-\mathrm{cm}$.) thallium-activated sodium iodide crystal, directed horizontally towards the patients, at a distance of 1 metre. The efficiency of counting was 300 counts per minute per $\mu \mathrm{c}$. of ${ }^{59} \mathrm{Fe}$, with a background of 360 counts per minute. The same standard meal was used except that the oral dose was given as ${ }^{59} \mathrm{Fe}$. The percentage absorption was calculated from the counting rates at five hours and that found 10 to 15 days later, when whole-body activity had reached a plateau. The results obtained with this method showed close agreement with those obtained by the double isotope technique done simultaneously (Pitcher et al., 1965).

\section{Results}

\section{Before Treatment}

Absorption was normal in six of the seven patients examined (Table I), but Case 3 had a slightly increased absorption of $15 \%$. The mean of 6.7 and range $1-15 \%$ did not differ significantly from the corresponding figures of 4.9 and $1-13 \%$ found in 38 control subjects (Pitcher et al., 1965). Included in this group is one patient (Case 2) who had received sporadic venesections totalling $7.5 \mathrm{l}$. over an 11 -month period three and a half years previously. At the time of the test he still had gross pigmentation, hepatomegaly, gonadal atrophy, and impaired glucose tolerance. Liver biopsy sections showed gross excess of iron comparable to that present initially. The other patients were seen soon after presentation and had not been venesected.

TABLE I.-Results in Seven Patients Examined Before Venesection Therapy

\begin{tabular}{c|c|c|c|c|c|c}
\hline $\begin{array}{c}\text { Case } \\
\text { No. }\end{array}$ & $\begin{array}{c}\text { Present } \\
\text { Age }\end{array}$ & $\begin{array}{c}\text { Haemo- } \\
\text { globin } \\
\text { (g./100 ml. })\end{array}$ & $\begin{array}{c}\text { M.C.H.C. } \\
(\%)\end{array}$ & $\begin{array}{c}\text { Serum } \\
\text { Iron } \\
(\mu \mathrm{g} . / 100 \mathrm{ml} .)\end{array}$ & $\begin{array}{c}\text { Saturation } \\
\text { T.I.B.C. } \\
(\%)\end{array}$ & $\begin{array}{c}\text { Iron } \\
\text { Absorption } \\
(\%)\end{array}$ \\
\hline 1 & 45 & 13.9 & 32 & 233 & 60 & 3 \\
2 & 61 & $14 \cdot 2$ & 32 & 98 & 100 & 3 \\
3 & 71 & $14 \cdot 1$ & 33 & 196 & 92 & 15 \\
4 & 52 & $14 \cdot 0$ & 34 & 173 & 79 & 6 \\
5 & 55 & $15 \cdot 0$ & 34 & 144 & 92 & 1 \\
6 & 49 & $15 \cdot 4$ & 35 & 255 & 87 & 7 \\
7 & 54 & 15.5 & 33 & 203 & - & 12 \\
\hline
\end{tabular}

M.C.H.C. $=$ Mean corpuscular haemoglobin concentration.

T.I.B.C. $=$ Total iron-binding capacity.

In one subject the absorption was determined simultaneously by both methods. On this occasion ${ }^{59} \mathrm{Fe}$ was used for the oral dose and ${ }^{36} \mathrm{Fe}$ for the intravenous one. Results of $3 \%$ for the double isotope method and $2 \%$ for the whole-body counter were obtained.

\section{During Venesection Therapy}

Nine patients were examined, including five in whom absorption had also been measured before venesections were started (Table II). In these the second measurement done 5 to 12 months later showed an increase in absorption over the pretreatment figure with values of $15-66 \%$ (Fig. 1). The other four patients were tested for the first time during venesection therapy and had absorptions of $11-39 \%$. Further measurements made in three of these patients towards the end of the treatment showed a further rise in absorption with values of $19-44 \%$.

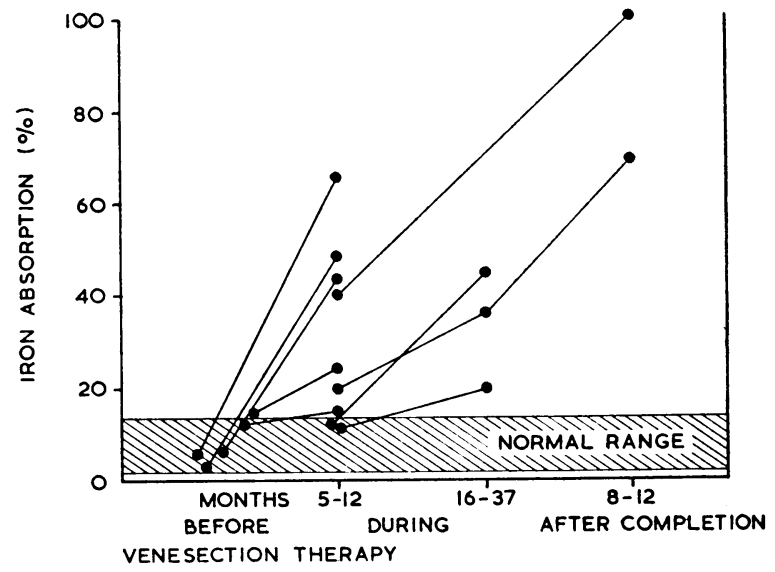

FIG. 1.- Serial readings of iron absorption in nine patients examined at various intervals in

TABLE II.-Results in Nine Patients Examined During Venesection Therapy. Cases 3-7 Had Also Been Examined Before Starting Treatment

\begin{tabular}{|c|c|c|c|c|c|c|c|c|}
\hline $\begin{array}{l}\text { Case } \\
\text { No. }\end{array}$ & $\begin{array}{c}\text { Present } \\
\text { Age }\end{array}$ & $\begin{array}{c}\text { Duration } \\
\text { of } \\
\text { Treat- } \\
\text { ment } \\
\text { (mth.) }\end{array}$ & $\begin{array}{c}\text { Iron } \\
\text { Removed } \\
\text { (g.) }\end{array}$ & $\begin{array}{c}\text { Haemo- } \\
\text { globin } \\
(\mathrm{g} . / \\
100 \mathrm{ml} .)\end{array}$ & $\underset{(\%)}{\text { M.C.H.C }}$ & $\begin{array}{c}\text { Serum } \\
\text { Iron } \\
(\mu \mathrm{g} . / \\
100 \mathrm{ml} .)\end{array}$ & $\begin{array}{c}\% \\
\text { Satura- } \\
\text { tion } \\
\text { T.I.B.C. }\end{array}$ & $\begin{array}{l}\text { Iron } \\
\text { Absorp- } \\
\text { tion } \\
(\%)\end{array}$ \\
\hline $\begin{array}{l}3 \\
4 \\
5 \\
6 \\
7\end{array}$ & $\begin{array}{l}71 \\
52 \\
55 \\
49 \\
54\end{array}$ & $\begin{array}{r}6 \\
8 \\
5 \\
12 \\
12\end{array}$ & $\begin{array}{r}2 \cdot 0 \\
6.5 \\
5.5 \\
6 \cdot 2 \\
12.5\end{array}$ & $\begin{array}{l}16 \cdot 2 \\
13.0 \\
12 \cdot 0 \\
14.0 \\
13 \cdot 8\end{array}$ & $\begin{array}{l}34 \\
34 \\
33 \\
30\end{array}$ & $\begin{array}{l}191 \\
230 \\
185 \\
254 \\
194\end{array}$ & $\begin{array}{l}88 \\
88 \\
69 \\
96 \\
91\end{array}$ & $\begin{array}{l}25 \\
66 \\
48 \\
43 \\
15\end{array}$ \\
\hline 8 & 56 & $\left\{\begin{array}{r}6 \\
22\end{array}\right.$ & $\begin{array}{r}5.5 \\
13.0\end{array}$ & $\begin{array}{l}11 \cdot 6 \\
11 \cdot 1\end{array}$ & $\begin{array}{l}31 \\
30\end{array}$ & $\begin{array}{l}140 \\
165\end{array}$ & $\begin{array}{l}70 \\
82\end{array}$ & $\begin{array}{l}11 \\
19\end{array}$ \\
\hline 9 & 56 & $\left\{\begin{array}{l}12 \\
37\end{array}\right.$ & $\begin{array}{r}6.8 \\
17.5\end{array}$ & $\begin{array}{l}13.6 \\
16.2\end{array}$ & $\begin{array}{l}33 \\
35\end{array}$ & $\begin{array}{l}200 \\
170\end{array}$ & $\begin{array}{l}89 \\
71\end{array}$ & $\begin{array}{l}11 \\
44\end{array}$ \\
\hline 10 & 66 & 6 & 3.0 & 15.8 & - & 224 & 77 & 39 \\
\hline 11 & 56 & $\left\{\begin{array}{r}5 \\
16\end{array}\right.$ & $\begin{array}{r}4 \cdot 4 \\
14 \cdot 5\end{array}$ & $\begin{array}{l}12 \cdot 0 \\
13 \cdot 1\end{array}$ & $\begin{array}{l}32 \\
30\end{array}$ & $\begin{array}{r}250 \\
63\end{array}$ & $\begin{array}{r}100 \\
22\end{array}$ & $\begin{array}{l}19 \\
35\end{array}$ \\
\hline
\end{tabular}

Though there was a correlation in the individual case between the height of the absorption and the duration of treatment, in the whole group there was no relation between absorption and the number of venesections or duration of treatment. Case 7 , in whom 50 venesections had been performed in one year, had one of the lowest absorption values. All the patients were bled $500 \mathrm{ml}$. weekly with the exception of Case 9, in whom venesections were done fortnightly. The tests were performed a week after the last bleeding, and, though all the patients had missed venesections, the frequency had been fairly constant during the preceding two months. It is apparent also from the findings in the patients who had been examined both before and during treatment that there was no correlation between the level of absorption during treatment and that present initially (Fig. 1).

\section{After Venesection Therapy}

Two of the 10 patients investigated had also had previous measurements made during the treatment period. The others were examined for the first time after venesection had been 
discontinued. In all the patients there was good evidence that the excess iron had been removed, for each had been bled until there was a sustained fall in haemoglobin and serum iron levels. In nine patients the removal of hepatic iron deposits was confirmed by liver biopsy; in Case 16 four venesections were performed in the 18-month interval between the two measurements done. None of the patients had maintenance venesection therapy.

Absorption was greatly increased during the first year after stopping therapy. The mean absorption in the six cases examined at this time was $65 \%$ and the range $41-100 \%$. Two of these were still anaemic. In the others the serum iron and haemoglobin levels had returned to normal and there was no correlation between the level of absorption and the haematological findings. The results in the two patients who had had previous measurements performed showed higher levels after treatment than during the venesection period (Fig. 1).

Serial measurements were made in eight patients during the subsequent follow-up period (Fig. 2). In five the absorption decreased, although in only one, a 78-year-old man, did it return to normal. In the other three patients the absorption either increased or remained at a high level, the final absorption values being 54,79 , and $73 \%$ at $4,2 \frac{1}{2}$, and $3 \frac{1}{2}$ years respectively after the completion of venesection therapy. Comparison of the latter patients with those in whom absorption fell revealed no significant difference. Clinically all were well, and in none had skin pigmentation or hepatomegaly recurred. One of the patients with a high absorption (Case 18) had diabetes, as compared with two of the group (Cases 12 and 16) in which absorption fell. Liver-function tests were normal in all cases, though cirrhosis, as judged histologically, was still present. Serum iron levels tended to rise progressively during the

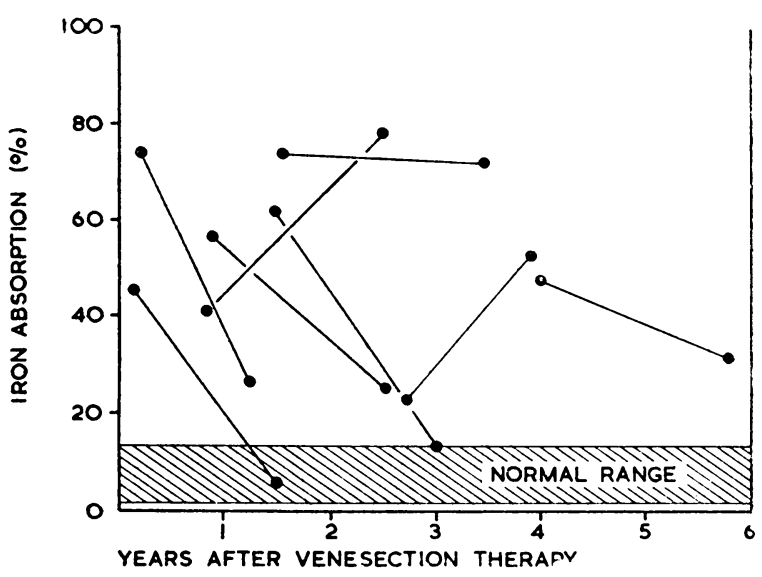

FIG. 2.-Serial readings of iron absorption in eight patients examined after completion of treatment.

Table III.-Results in 10 Patients Examined After Completion of Venesection Therapy. Cases 10 and 11 had also been Examined During the Treatment Porlod

\begin{tabular}{|c|c|c|c|c|c|c|c|c|}
\hline $\begin{array}{c}\text { Case } \\
\text { No. }\end{array}$ & $\begin{array}{c}\text { Present } \\
\text { Age }\end{array}$ & $\begin{array}{c}\text { Time } \\
\text { Aftex } \\
\text { Comple- } \\
\text { tion } \\
\text { (mth.) }\end{array}$ & $\underset{\substack{\text { Removed } \\
\text { (g.) }}}{\text { Iron }}$ & $\begin{array}{c}\text { Haemo- } \\
\text { globin } \\
(\mathrm{g} . / \\
100 \mathrm{ml} .)\end{array}$ & $\underset{(\%)}{\text { M.C.H.C. }}$ & $\begin{array}{c}\text { Serum } \\
\text { Iron } \\
(\mu \mathrm{g} .1 \\
100 \mathrm{ml} .)\end{array}$ & $\begin{array}{c}\% \\
\text { Satura- } \\
\text { tion } \\
\text { T.I.B.C. }\end{array}$ & $\begin{array}{l}\text { Iron } \\
\text { Absorp- } \\
\text { tion } \\
(\%)\end{array}$ \\
\hline $\begin{array}{l}10 \\
11 \\
12\end{array}$ & $\begin{array}{l}66 \\
56 \\
78\end{array}$ & $\begin{array}{r}11 \\
8 \\
1\end{array}$ & $\begin{array}{l}12 \cdot 3 \\
15 \cdot 0 \\
34 \cdot 0\end{array}$ & $\begin{array}{r}15.8 \\
13.8 \\
8.5\end{array}$ & $\begin{array}{l}33 \\
33 \\
31 \\
32\end{array}$ & $\begin{array}{r}130 \\
87 \\
17\end{array}$ & $\begin{array}{r}41 \\
42 \\
5\end{array}$ & $\begin{array}{r}100 \\
69 \\
45\end{array}$ \\
\hline 13 & 51 & $\begin{array}{r}18 \\
2\end{array}$ & $\begin{array}{l}34.0 \\
21 \cdot 0\end{array}$ & $\begin{array}{l}15.1 \\
11.9\end{array}$ & $\begin{array}{l}33 \\
28\end{array}$ & $\begin{array}{r}205 \\
47\end{array}$ & $\begin{array}{l}92 \\
25\end{array}$ & $\begin{array}{r}5 \\
74\end{array}$ \\
\hline & & 15 & 21.0 & 15.2 & 34 & 170 & & 27 \\
\hline 14 & 58 & 10 & $\begin{array}{l}13.8 \\
13.8\end{array}$ & 14.8 & 33 & 200 & 87 & 57 \\
\hline 15 & 60 & $\begin{array}{l}30 \\
10\end{array}$ & $\begin{array}{l}13.8 \\
21.3\end{array}$ & $\begin{array}{l}15.1 \\
13.6\end{array}$ & $\begin{array}{l}34 \\
31\end{array}$ & $\begin{array}{l}116 \\
170\end{array}$ & 65 & $\begin{array}{l}26 \\
41\end{array}$ \\
\hline 10 & $\infty$ & 29 & $21 \cdot 3$ & 14.9 & 33 & 198 & 93 & 79 \\
\hline 16 & 53 & 17 & $19 \cdot 0$ & $15 \cdot 0$ & 32 & 75 & 34 & 62 \\
\hline 17 & & $\begin{array}{l}36 \\
18\end{array}$ & $\begin{array}{l}20.0 \\
20.0\end{array}$ & $\begin{array}{l}13.6 \\
14.4\end{array}$ & $\begin{array}{l}30 \\
32\end{array}$ & $\begin{array}{r}76 \\
120\end{array}$ & $\begin{array}{l}19 \\
44\end{array}$ & $\begin{array}{l}13 \\
74\end{array}$ \\
\hline 10 & & & 20.0 & $17 \cdot 2$ & 34 & 225 & 91 & 73 \\
\hline 18 & 57 & 33 & $\begin{array}{l}25 \cdot 0 \\
25.0\end{array}$ & $\begin{array}{l}15.1 \\
15.8\end{array}$ & $\begin{array}{l}34 \\
33\end{array}$ & $\begin{array}{r}62 \\
200\end{array}$ & $\begin{array}{r}25 \\
100\end{array}$ & $\begin{array}{l}22 \\
54\end{array}$ \\
\hline 19 & 56 & 48 & 18.8 & 14.8 & 29 & 40 & & 49 \\
\hline & 1 & 69 & $18 \cdot 8$ & & 30 & & 25 & 33 \\
\hline
\end{tabular}

follow-up period, and six patients had values of $170 \mu \mathrm{g} . / 100$ $\mathrm{ml}$. or over at the time of the last absorption. Although three patients had been classed initially as heavy drinkers, in only one (Case 17) was there evidence that this was continuing.

The plasma iron turnover was measured in six patients at a time when the absorption was increased (Table IV). In one patient the value was normal. In the others it was increased or close to the upper limit of the normal range. In four of the latter five patients this high turnover was associated with a prolonged or normal half-time of the injected radio-iron and a raised or normal serum iron level. The fifth patient had a slightly reduced half-time and low serum iron level at the time of the test. Surface counting was carried out in the one patient with a normal turnover (Case 14) and in two of those in whom it was increased (Cases 10 and 17). The pattern was abnormal in all three and showed an increased hepatic uptake of iron. This was particularly marked in Case 17.

TABLB IV.-Plasma Iron Turnover Measurements in Six Patients Examined aftor Completion of Venesection Therapy, Together with Nearest Corresponding Absorption Value

\begin{tabular}{c|c|c|c|c|c|c}
\hline Case & $\begin{array}{c}\text { Time after } \\
\text { Venesection } \\
\text { Therapy } \\
\text { (months) }\end{array}$ & $\begin{array}{c}\text { Iron } \\
\text { Absorp- } \\
\text { tion } \\
(\%)\end{array}$ & $\begin{array}{c}\text { Serum } \\
\text { Iron } \\
(\mu \mathrm{g} .1 \\
100 \mathrm{ml} .)\end{array}$ & $\begin{array}{c}\text { Plasma } \\
\text { s9 Fe } \\
\text { T. } \\
\text { (mins.) }\end{array}$ & $\begin{array}{c}\text { Plasma-iron } \\
\text { Turnover } \\
\text { (mg./ } \\
\text { kg./day) }\end{array}$ & $\begin{array}{c}\text { Incorporation } \\
\text { in } \\
\text { Red Cells } \\
(\%)\end{array}$ \\
\hline 10 & 6 & 100 & 145 & 86 & 0.71 & 66 \\
14 & 30 & 26 & 74 & 72 & 0.42 & 85 \\
15 & 29 & 79 & 198 & 126 & 0.66 & 53 \\
17 & 41 & 73 & 153 & 109 & 0.55 & 73 \\
18 & 47 & 54 & 157 & 56 & 1.17 & 91 \\
19 & 69 & 33 & 55 & 36 & 0.57 & 83 \\
\hline
\end{tabular}

\section{Discussion}

The present findings, together with those of Pirzio-Biroli et al. (1958) and of Chodos et al. (1957), show that iron absorption in idiopathic haemochromatosis is normal or only marginally increased at the time of presentation. The high results reported by other workers (reviewed by Williams and Pitcher, 1963 ; MacDonald, 1964) are probably due to errors in complete stool collections or to the unphysiological nature of the test procedure used, such as the administration of ferrous iron salts to fasting subjects. The iron solution given in the present technique mixes with most of the iron present in the meal, and the range of values found in normal subjects agrees closely with those obtained from the use of foodstuffs into which iron has been incorporated biosynthetically (Moore, 1964 ; Pitcher et al., 1965). Dietary iron intake was normal in the present patients, and though the percentage absorption was also normal it may be regarded as abnormal in the sense that the amount absorbed was in excess of body needs. If iron stores are increased experimentally in animals the absorption decreases, and there is some evidence that the same mechanism is present in man (Bothwell and Finch, 1962). It is possible, therefore, that absorption would be lower in normal subjects with a comparable degree of iron overload.

Increased absorptions were found during venesection therapy even at a time when the iron stores were still considerably increased. This is consistent with the findings of Weintraub et al. (1964a), who showed that absorption increased to the same extent in an iron-overloaded group of venesected rats as in controls with normal iron stores. Recent studies in man also suggest that the main factor controlling iron absorption is the rate of erythropoiesis and plasma iron turnover rather than the state of the iron stores (Weintraub et al., 1964b). The plasma iron turnover is believed to influence the amount of "messenger" iron present in intestinal mucosal cells (Conrad et al., 1964). Markedly increased absorptions were found in the present patients towards the end of treatment when there were signs of iron deficiency, and during the first year after therapy 
had been discontinued. Crosby et al. (1963) suggested that absorption is greater in patients with haemochromatosis rendered anaemic by treatment than in other varieties of irondeficiency anaemia. They calculated the amount of iron absorbed from the time of venesection until the haemoglobin level had returned to normal and found values of $8-10 \mathrm{mg}$. daily in haemochromatosis, as compared with 3-6 mg. daily in normal or polycythaemic subjects examined after phlebotomy.

The results obtained during the follow-up period after anaemia had been corrected showed that the absorption, with one exception, remained abnormal and indeed in two cases had climbed during this period. Bothwell et al. (1958) state that iron absorption rapidly returns to normal in control subjects once anaemia has been corrected. Their evidence was indirect, and values of 64 and $71 \%$ were found by Conrad and Crosby (1962) in two control subjects with normal haemoglobin and serum iron levels examined 6 to 12 months after phlebotomy. However, Weintraub et al. (1964a) have shown that animals subject to partial hepatectomy, with consequent decrease in storage iron but no anaemia, have the same absorption as shamoperated animals. It also seems unlikely that the present patients with absorptions of $50-70 \%$ during the first year could still have significant iron depletion after that period, since this rate of absorption should have restored the normal stores of approximately $1 \mathrm{~g}$. in 9 to 12 months. Furthermore, Crosby et al. (1963) found stores of 2 and $3 \mathrm{~g}$. in two treated patients with haemochromatosis who had further venesections after an interval of two years, which is further evidence that absorption is abnormally high.

A number of factors apart from a basic defect in absorption might be responsible for the increased values demonstrated in the majority of patients after venesection treatment. An increased absorption has been demonstrated in cirrhosis due to other causes (Conrad et al., 1962 ; Greenberg et al., 1964). The mechanism is uncertain, but there appears to be some relation between absorption and the type of cirrhosis and presence of a surgical shunt (Williams et al., 1966). In the present patients the cirrhosis was inactive by all criteria and none showed evidence of a large collateral circulation. Pancreatic deficiency has been implicated as a cause of increased absorption both in cirrhosis and in haemochromatosis (Callender and Malpas, 1963 ; Davis and Biggs, 1964). In the present cases there was no correlation between absorption and the presence of pancreatic damage as evidenced by diabetes.

The turnover measurements would also suggest a primary defect in iron metabolism. Four of the six examined showed a similar pattern to that which has been described in idiopathic haemochromatosis before treatment, the half-time of the injected radio-iron being either prolonged or in the normal range despite the increase in plasma iron, and the iron turnover therefore increased. The latter is thought to indicate an increased exchange of iron between the plasma and storage pools, the amount going to the erythroid precursors being the same as normal (Finch and Finch, 1955; Pollycove and Mortimer, 1961 ; Dreyfus and Schapira, 1964 ; Kimber et al., 1965). Although it is possible that the increased turnover after completion of venesection therapy was related to some persisting effect on the rate of erythropoiesis, surface counting showed diversion of iron to the liver rather than to erythropoietic sites. However, it is surprising, if the rate of plasma iron turnover is the main factor regulating absorption, that the increased turnover found at the time of presentation is not accompanied by a higher absorption. Unfortunately patients are rarely seen during the early stages of the disease, but it is hoped that prolonged follow-up of the patients already treated will throw further light on the factors responsible for the accumulation of iron and its relation to tissue damage.

\section{Summary}

Iron absorption was measured serially in 19 patients with idiopathic haemochromatosis at various intervals in relation to venesection therapy. Values were normal or only marginally increased at the time of presentation. During venesection therapy the absorption increased progressively. High levels were found towards the end of treatment, though in two cases absorption was markedly increased (66 and $48 \%$ ) during the first few months, when iron stores were still considerably increased.

In five out of eight patients examined after completion of treatment the absorption subsequently decreased, though in only one did it return to normal. In three patients the absorption climbed or was maintained at a high level. The increased absorption during the follow-up period could not be accounted for by persistence of anaemia or depletion of iron stores. Plasma iron turnover was increased and surface counting showed diversion of iron to the liver.

The findings were consistent with a primary defect in absorption, which had been depressed by the time of presentation as a result of saturation of iron stores.

Drs. P. Dick, M. Hamilton, and W. C. Smallwood kindly allowed us to examine patients under their care. Mr. A. Parsonson and $\mathrm{Mr}$. J. Agnew gave valuable technical assistance. The work was supported by the Medical Research Council.

\section{REFERENCES}

Bothwell, T. H., Callender, S., Mallett, B., and Witts, L. J. (1956). Brit. f. Haemat., $2,1$.

and Finch, C. A. (1962). Iron Metabolism. Churchill, London.

Pirzio-Biroli, G., and Finch, C. A. (1958). ๆ. Lab. clin. Med., 51, 24.

Callender, S. T., and Malpas, J. S. (1963). Brit. med. f., 2, 1516.

Chodos, R. B., Ross, J. F., Apt, L., Pollycove, M., and Halkett, J. A. E. (1957). F. clin. Invest., 36, 314.

Conrad, M. E., Berman, A., and Crosby, W. H. (1962). Gastroentero$\log y, 43,385$.

- and Crosby, W. H. (1962). Blood, 20, 173

— Weintraub, L. R., and Crosby, W. H. (1964). F. clin. Invest., 43, 963.

Crosby, W. H., Conrad, M. E., and Wheby, M. S. (1963). Blood, 22,

Dacie, J. V., and Lewis, S. M. (1963). Practical Haematology, 3rd ed. Churchill, London.

Davis, A. E., and Biggs, J. C. (1964). Aust. Ann. Med., 13, 201.

Dreyfus, J. C., and Schapira, G. (1964). In Iron Metabolism, edited by F. Gross, S. R. Naegeli, and H. D. Philps. Springer, Berlin.

Finch, S. C., and Finch, C. A. (1955). Medicine (Baltimore), 34, 381.

Greenberg, M. S., Strohmeyer, G., Hine, G. J., Keene, W. R., Curtis, G., and Chaimers T. C. (1964). Gastroenterology, 46, 651.

Kimber, C., Deller, D. J., Ibbotson, R. N., and Lander, H. (1965). Quart. $₹$. Med., 34, 33.,

MacDonald, R. A. (1964). Hemochromatosis and Haemosiderosis. Thomas, Springfield, Illinois.

Moore, C. V. (1964). In Iron Metabolism, edited by F. Gross, S. R. Naegli, and H. D. Philps. Springer, Berlin.

Peterson, R. E., and Ettinger, R. H. (1953). Amer. \%. Med., 15, 518.

Pirzio-Biroli, G., Bothwell, T. H., and Finch, C. A. (1958). \%. Lab. clin. Med., 51, 37.

Pitcher, C. S., Williams, H. S., Parsonson, A., and Williams, R. (1965). Brit. f. Haemat., 11, 633.

Pollycove, M., and Mortimer, R. (1961). f. clin. Invest., 40, 753.

Ramsay, W. N. M. (1957). Clin. chim. Acta, 2, 214, 221.

Ramsay, W. N. M. (1957). Clin. Chim. Amer.' F. 'Physiol., 172, 372.

Saylor, L., and Finch, C. A. (1953). Amer. F. Physiol., 172, 372. 53.

Sheldon, J. H. (1935). Haemochromatosis. Oxford Univ. Press, London.

Weintraub, L. R., Conrad, M. E., and Crosby, W. H. (1964a). Y. clin. Invest., 43, 40.

Till (1964b). Blood, 24, 19.

Williams, R., Williams, H. S., Scheuer, P. J., Pitcher, C. S., Loiseau, E., and Sherlock, S. (1966). In preparation. and Pitcher, C. S. (1963). Postgrad. med. 7., 39, 193.

- and Pitcher, C. S. (1963). Postgrad. med. F. 395). Lancet, 1, 1243. 